\title{
Mammals' antimicrobial peptides: potential and limitations for the treatment of Staphylococcus aureus infections
}

\author{
Peptídeos antimicrobianos de mamíferos: potencial e limitações para o \\ tratamento de infeç̧ões por Staphylococcus aureus
}

\section{Gabriel Bernardes Baron ${ }^{1 *}$, Nathália Franchon Marques Tejada ${ }^{{ }^{*}}$, Fabiano Pinheiro da Silva ${ }^{2}$} Baron GB, Tejada NFM, Pinheiro da Silva F. Mammals' antimicrobial peptides: potential and limitations for the treatment of
Staphylococcus aureus infections / Peptídeos antimicrobianos de mamíferos: potencial e limitações para o tratamento de infecções por Staphylococcus aureus. Rev Med (São Paulo). 2018 jan.-fev.;97(1):59-70.

ABSTRACT: Antimicrobial peptides (AMPs) are small molecules produced by virtually all living organisms as a part of the innate immune system. They present a broad spectrum antimicrobial activity against a myriad of microorganisms, but also anti-inflammatory, immunomodulatory and antitumor effects, among others. Therefore, it was our objective to compile and analyze the current information about natural and synthetic AMPs, regarding their general mechanisms of action, potentials, and limitations for clinical use, especially for the treatment of Staphylococcus aureus infections. Furthermore, we intended to briefly discuss new routes of administration and the emergence of bacterial resistance to AMPs. To do so, two databases, PubMed and Scopus, and the keywords "Staphylococcus aureus", "antimicrobial peptide" and "novel antibiotics" were used, and the articles were filtered by the English language for the period between 2011 and 2016. We found that AMPs possess different properties, with characteristic antimicrobial activities and secondary effects. Moreover, we also pointed some modifications that could be used to design new AMPs and different routes of administration that could be used to improve AMP capacity or to adapt it to a specific purpose, such as preventing biofilm formation in catheters or treating a specific disease. On the other hand, they also present limitations that include: development of bacterial resistance, cytotoxicity, and reduced stability, sometimes lower efficacy when compared to the actual treatment, high costs of production and also some inconsistent results between articles, which we believe that may be related to differences in methods and/or strains of $S$. aureus investigated.

Keywords: Anti-bacterial agents/adminstration \& dosage; Reference drugs; Staphylococcus aureus/drug effects; Staphylococcal infections/ prevention \& control; Staphylococcus aureus/drug therapy.
RESUMO: Peptídeos antimicrobianos (AMPs) são pequenas moléculas conservadas evolutivamente e encontradas virtualmente em todos os organismos vivos como parte de sua imunidade inata. Eles possuem um amplo espectro de atividade antimicrobiana contra diversos microrganismos, mas também ação anti-inflamatória, imunomodulatória, antitumoral, dentre outros efeitos. Desse modo, nosso objetivo foi compilar e analisar as informações mais atuais sobre AMPs naturais e sintéticos, considerando seus mecanismos gerais de ação, bem como seu potencial e limitações para uso clínico, especialmente no tratamento de infecções por Staphylococcus aureus. Além disso, discutimos brevemente o uso de novas vias de administração e a possibilidade do desenvolvimento de resistência bacteriana aos AMPs. Para tanto, foram usadas duas bases de dados, PubMed e Scopus e os descritores "Staphylococcus aureus", "peptídeos antimicrobianos" e "novos antibióticos". Os artigos foram filtrados para a língua inglesa e foram selecionadas publicações entre 2011 e 2016. Os resultados foram em sua maioria compatíveis com o que se obteve em revisões prévias, a saber, que existe uma grande variedade de AMPs, cada qual com características, atividades antimicrobianas e efeitos secundários específicos. Ademais, também foram apontadas modificações que podem ser usadas para o planejamento de novos AMPs e diferentes vias de administração que podem ser usadas para aprimorar os potenciais de um AMP, ou adaptá-lo para um propósito específico, como a prevenção de formação de biofilmes em cateteres ou no tratamento de uma doença específica. Por outro lado, eles também possuem limitações, que incluem: desenvolvimento de resistência bacteriana, citotoxicidade e reduzida estabilidade, eventualmente baixa eficácia quando comparados ao tratamento atual, elevados custos de produção, e mesmo inconsistências de resultados entre artigos, o que acreditamos estar relacionado a diferenças no método e/ou a cepa de $S$. aureus usados.

Descritores: Antibacterianos/administração \& dosage; Medicamentos de referência; Staphylococcus aureus/efeitos de drogas; Infecções estafilocócicas/prevenção \& controle; Staphylococcus aureus/tratamento farmacológico.

\footnotetext{
* Joint first authors.

Artigo desenvolvido na Disciplina Optativa "Abordagem Prática da Escrita Científica" sob coordenação da Revista de Medicina do DC-FMUSP

1. Faculdade de Medicina FMUSP, Universidade de São Paulo, São Paulo, SP, Brazil. E-mails: gabriel.baron@fm.usp.br, http://orcid.org/0000-00032816-0607; nathalia.franchon@fm.usp.br, http://orcid.org/0000-0002-2200-3566.

2. Departamento de Emergências Clínicas, Faculdade de Medicina FMUSP, Universidade de São Paulo, São Paulo, SP, Brazil. E- mail: pinheirofabiano@ hotmail.com, http://orcid.org/0000-0003-2673-2202.

Corresponding author: Nathália Franchon Marques Tejada. Faculdade de Medicina FMUSP, Universidade de São Paulo. Av. Dr. Arnaldo, 455. Cerqueira César - São Paulo, SP, Brazil. CEP: 01246-903. Email: nathalia.franchon@fm.usp.br.
} 


\section{INTRODUCTION}

ntimicrobial peptides (AMPs) are small, amphipathic and polycationic peptides, for the most part between 12 and 50 amino acids, that can exhibit linear structure, among which are included $\alpha$-helical AMPs, or a circular structure, containing one or more disulfide bridges forming a $\beta$-sheet ${ }^{1}$. They are naturally produced, either constitutively or after a microbial stimulus ${ }^{2}$, and by a great variety of organisms, such as bacteria, fungi, plants, invertebrate animals, and mammals, including humans - in whom form an important line of defense of the innate immune response. AMPs commonly act through nonspecific mechanisms ${ }^{3}$. Because of this, it has been extensively discussed by the scientific community whether or not their widespread therapeutic application can induce resistance, and if the use of AMPs could lead to the same problems as those we face nowadays related to the indiscriminate use of antibiotics.

However, due to their capability to disrupt bacteria structure, recognize antigens and modulate innate immune response ${ }^{1}$, AMPs may be considered a potential novel alternative for the treatment of infections, such as those caused by antibiotic-resistant bacteria. Among them, Staphylococcus aureus infections deserve special attention, since they are frequent in the community and hospital settings, induce biofilm formation in medical devices ${ }^{4,5}$ and include highly virulent and resistant strains, such as methicillin-resistant $S$. aureus (MRSA) and vancomycinresistant $S$. aureus (VRSA) ${ }^{4,5}$, which are related to complications and worse prognostic in intensive care unit patients.

However, scientists still face several questions and challenges related to the clinical use of AMPs for the treatment of severe infections ${ }^{6}$, such as their toxicity and non-specificity, effectiveness, stability, ways of application, selectivity, microorganism resistance, cross-resistance to human AMPs, proteolytic degradation ${ }^{7}$, peptide selfaggregation $^{8}$, high production costs, among others. Possible solutions include the synthetic/modified AMPs, molecules with the same basic characteristics of natural AMPs, but with certain synthetic modifications to reduce their toxicity, Minimum Inhibitory Concentration (MIC) and sensitiveness to protease activity, while maintaining (or increasing) its antibiotic potential ${ }^{9}$.

Thus, the present review aims to discuss the potentials and limitations of natural and synthetic AMPs for the treatment of $S$. aureus infections, focusing in the peptides produced in mammals or derived from them.

\section{METHODS}

In purpose to analyze the above theme, two databases were used: PubMed and Scopus, both accessed in October 2016.

\section{Inclusion and exclusion criteria}

We considered articles in the English language published between 2011 and 2016 .

Review articles, those not available on open access or through University of São Paulo's subscripts, those that primarily investigated a new methodology, other diseases, or immune, genetics and biochemistry mechanisms associated with AMPs were excluded.

\section{Selection strategy}

In PubMed, the search using the keywords "Staphylococcus aureus", "antimicrobial peptide" and "novel antibiotics", all together and without quotation marks, achieved 228 articles. In Scopus, the keywords "Staphylococcus aureus", "antimicrobial peptide" and "antibiotics", were used with quotation marks, resulting in 346 articles.

Primarily, the selected articles had their title evaluated based on the exclusion criteria. With this step, we reached 178 articles from PubMed and 346 articles from Scopus. They were unified and the repeated articles were excluded. Afterward, we got 377 articles, which had the abstract analyzed by the exclusion criteria, resulting in 177 articles.

Subsequently, these articles were classified by the origin of the AMP. As some articles approach more than one peptide, these were counted in more than one group, so that we had: Bacteria (22 articles), Protists (1 article), Fungi (5 articles), Plants (6 articles), Synthetics (36 articles), Invertebrates (34 articles), Fishes ( 8 articles), Amphibians (34 articles), Reptiles (5 articles), Birds (2 articles) and Mammals (34 articles). Aiming to detail a specific theme, the Mammals (34 articles) and Synthetic Mammals (12 articles) articles were chosen for the review, given that they are one of the most studied, and the evolutionary similarity of some of them with human AMPs could eventually reduce adverse effects. Besides the selected articles, we added five reviews, two of them of 2017, to improve our knowledge about AMPs general mechanisms of action and resistance. 


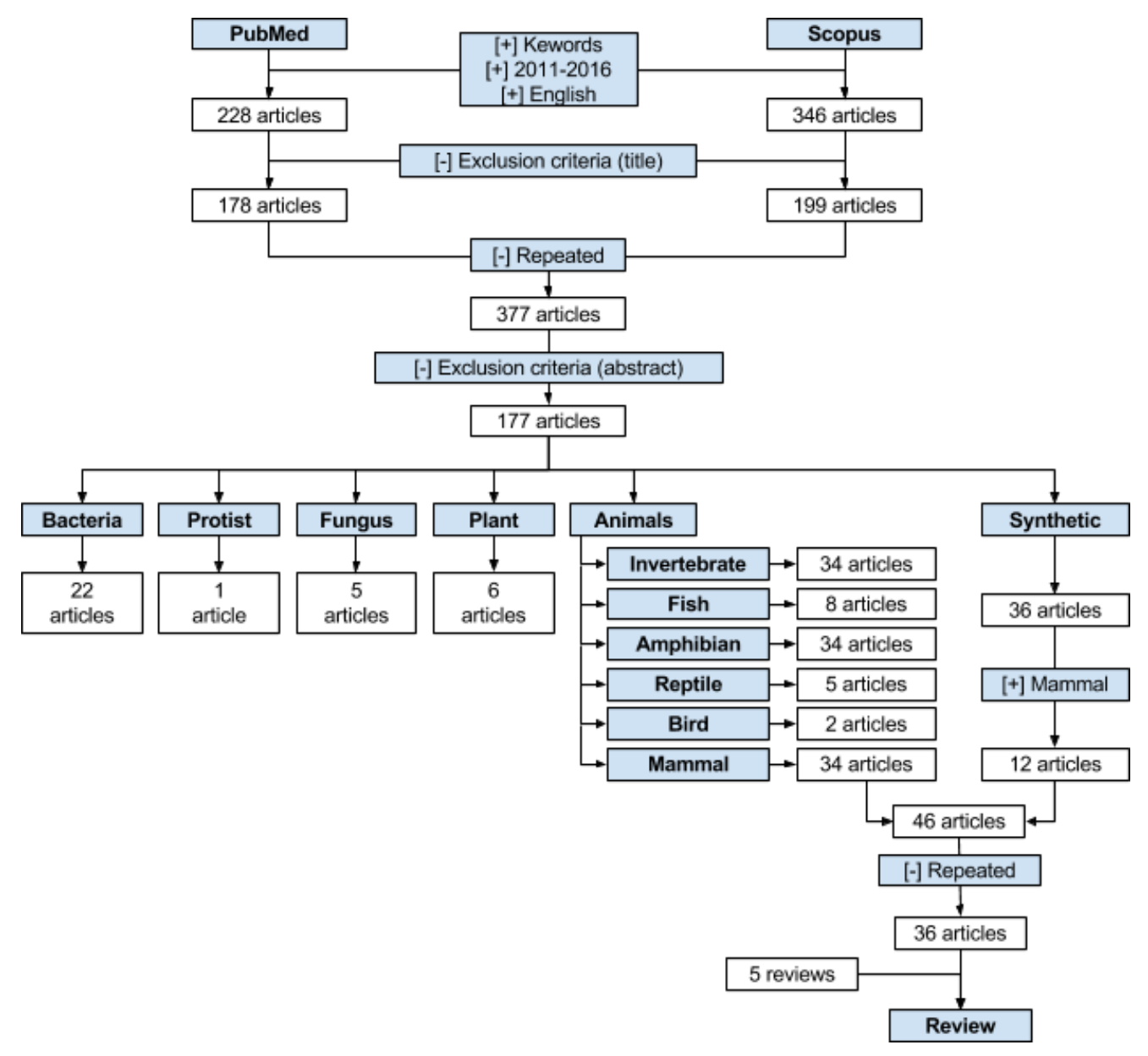

Figure 1. Methods - Selection flowchart for the articles

\section{RESULTS/DISCUSSION}

The articles comprised, in general, information about how peptides act, bacterial resistance to them, favorable and unfavorable results for both natural and synthetic AMPs, and the possibilities for AMP administration. Thus, we divided the review into the 7 topics below, gathering MIC information in two tables, and toxicity information in two other tables.

\section{Mechanisms of action}

Due to their cationic characteristics, AMPs can steadily bind to negative charge components of the bacterial membrane, such as anionic phospholipids and lipoteichoic acids, which explains, in part, their preferential binding to bacterial membrane than eukaryotic zwitterionic amphipathic cell membrane ${ }^{10}$.

After binding to the bacterial membrane, AMPs act through either one of two different general mechanisms: I) disruption of the plasmatic membrane, causing cell permeabilization and leakage (membrane-targeting AMPs), and II) targeting specific intracellular components (intracellular-targeting AMPs) ${ }^{11}$. The majority of AMPs works by the first mechanism, which can occur either by forming pores (toroidal pore model), destabilizing the lipid bilayer (barrel-stave model) or by thinning the membrane (carpet model) ${ }^{3}$, ultimately promoting bacterial cell lysis. Regarding the second mechanism, AMPs can cross bacterial membrane without inducing permeabilization, by direct penetration or endocytosis, and interact with essential negative charged molecules, such as DNA, RNA, and proteins, interfering or inhibiting them ${ }^{3}$. Both mechanisms are non-specific, once it does not involve specific receptors, and attack essential parts of the bacterial cell. For that, AMPs resistance was believed to be rare ${ }^{1}-$ but now it is known that it is not impossible, and it has been increasingly detected. Indeed, bacteria exposed to sublethal doses of AMPs in vitro showed resistance, and sometimes, antibiotics cross-resistance ${ }^{10}$.

Besides their direct antimicrobial activity, AMPs may also possess immune modulatory activities ${ }^{12}$.

\section{Bacterial resistance to AMPs}

Considering the wide and unspecific mechanisms of action of AMPs, as well as the secular existence of 
these molecules, it is not unexpected that pathogens developed mechanisms "to dodge" this immune defense pathway. These resistance mechanisms follow three major approaches: I) inhibition of AMPs binding or entry into the bacterial cell, II) removal of AMPs that got into the pathogen cell, and III) modulation of host's AMPs production. For S. aureus, the first and last strategies are the most frequent.

Concerning the inhibitory effects, $S$. aureus is capable of changing its surface charge, so it becomes less negative, thus limiting AMPs interaction. For example, it modifies its teichoic acid through D-alanylation encoded by the dltABCD operon, or through aminoacylation with L-alanine or L-lysine encoded by the $m p r F$ gene. Curiously, several host AMPs can paradoxically favor these modifications, restricting their own antimicrobial function. LL-16, for example, can naturally induce Dap, which is an operon of lysine biosynthesis enhancing, thus, this amino acid production. Analogously, brilacidin induces GraSR, a MprF member, even in doses as lower as MIC and quickly than LL-16 $6^{13}$. The importance of these pathways is still reaffirmed once $S$. aureus null mutants of either dlt or mprf genes become more susceptible to mammalian AMPs, especially to defensins ${ }^{14}$.

Besides the teichoic acid, $S$. aureus also protects its surface by other molecules. The incorporation of longchain unsaturated fatty acids in the bacterial membrane, for example, increases $S$. aureus resistance for platelet-derived AMPs. In the same way, staphylokinase either inactivates some AMPs, such as mCRAMP and alpha-defensins, or enhances tissue invasion ${ }^{14}$.

The production of other extracellular molecules by S. aureus is also known to limit AMP action ${ }^{15}$. For instance, the V8 protease is capable to degrade LL- $37^{5}$ and several other $S$. aureus' molecules are capable of inhibiting LL-37 and different AMPs by forming molecular complexes with low stability ${ }^{16}$.

Finally, $S$. aureus has an efflux system that actively removes AMPs that enter the cell. One of the major pumps is QaCA, a protein encoded by the commonly found pSK1 plasmid, which already induced platelet AMP resistance in rabbits and possibly promotes changes in membrane fluidity ${ }^{14}$. Brilacidin and LL-16 act in similar pathways, encoding genes that enhance $\mathrm{ABC}$ transporters, which are responsible for the active efflux of $\mathrm{AMPs}^{13}$.

\section{Therapeutic potential and limitations to the treatment of $S$. aureus infection}

AMPs can be natural or synthetic - and not necessarily synthetic compounds are better than the natural ones $^{3,9}$. Some also present secondary effects that may improve their clinical use, such as inhibition of biofilm formation and/or biofilm disruption. This is of great importance in clinical scenarios, as biofilm formation in medical devices (catheters, implants) $)^{5,17,18}$ and skin wounds have major implications.

AMPs also have some limitations, varying among them, which are related mostly to cytotoxicity/low selectivity ${ }^{3,19}$, low stability ${ }^{19,20}$, and others, both for natural and synthetic AMPs.

\section{Potentials of natural AMPs}

Although both bacterial evasion and general limitations of AMPs may impair some of their actions, several peptides are bacteriostatic or bactericidal (Table 1) and play other beneficial roles, such as reduction of inflammatory effects, participation in wound healing, immune modulation and even antitumoral activity.

Concerning bacteriostatic activity, some AMPs, such as HNP-1 and HNP-2, can only control pathogen growth by inhibiting exotoxins production, without altering $\mathrm{CFUs}^{24}$, while others, such as BMAP-28 and LL-37, can inhibit biofilm formation and also kill bacteria. Particularly, LL-37 achieves significant results, reducing $S$. aureus in nanomolar concentration ${ }^{7}$, ameliorating pneumonia in rats and destroying biofilms ${ }^{4}$. Nonetheless, despite these potentials, some researches ${ }^{33}$ already demonstrated better results in $S$. aureus elimination using modified AMPs than using natural ones. This occurs, for example, when NFL20 achieve, in comparison to LL-37, the double rate of survival of human-cell lines in an in vitro toxicity test, and a higher bacterial killing in a plasma assay ${ }^{33}$, showing that novel AMPs could be more efficient than those that are traditionally studied, deserving researchers' attention.

These factors and comparisons of new therapeutic possibilities are even more important when the AMPs' response is analyzed for bacteria resistant to some traditional antibiotics, once it would be desired that these novel molecules be either better or as efficacious as them. This indeed occurred in some experiments, such as when Kowalski et al. ${ }^{30}$ demonstrated that brilacidin has antimicrobial activity against vancomycin-resistant $S$. aureus infection in rabbits' damaged-cornea, and when Tai et al. ${ }^{25}$ showed the capability of specific alpha- (Crp-4 and RMAD-4) and theta-defensin (RTD-I) to reduce MRSA in vitro.

On the other hand, ambiguous and negative results were also found. In experiments testing BMAP-27, BMAP28 and P19(9/B), these peptides not only got higher MIC values for $S$. aureus than tobramycin (the antibiotic of choice used for chronic suppressive therapy in Cystic Fibrosis patients) but also lower bactericidal activity in a "Cystic Fibrosis-like" in vitro experiment - acidic $\mathrm{pH}$ (6.8), reduced $\mathrm{O}_{2}$ tension $\left(5 \% \mathrm{CO}_{2}\right)$, and a chemically defined "synthetic CF sputum medium" mimicking the nutritional composition of CF sputum ${ }^{28}$. In another study, the peptide catestatin reached a maximum of $40 \%$ of the efficiency of tetracycline and cefotaxime in controlling $S$. aureus growth in vitro ${ }^{17}$, showing that it could not replace the current antibiotic therapy. 
Table 1. Natural AMPs MICs with corresponding strain and references

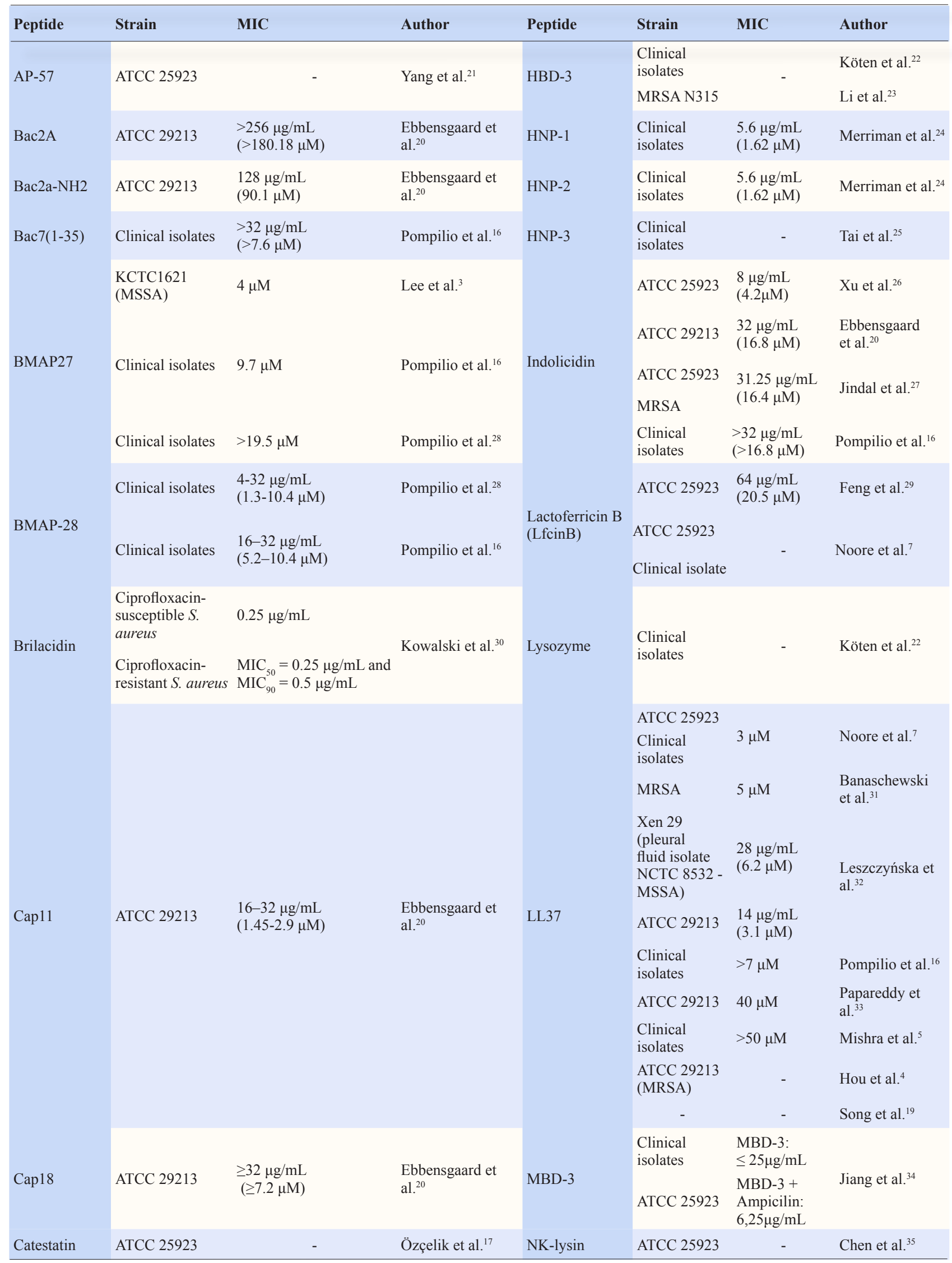


Table 1. Natural AMPs MICs with corresponding strain and references

Continuation

\begin{tabular}{|c|c|c|c|c|c|c|c|}
\hline Peptide & Strain & MIC & Author & Peptide & Strain & MIC & Author \\
\hline $\begin{array}{l}\text { Cathelicidin- } \\
\text { AM }\end{array}$ & ATCC 2592 & $\begin{array}{l}6.5 \mu \mathrm{g} / \mathrm{mL} \\
(1.5 \mu \mathrm{M})\end{array}$ & Yan et al. ${ }^{36}$ & P3 & ATCC 29213 & $\begin{array}{l}25 \mu \mathrm{g} / \mathrm{mL} \\
\text { (standard } \\
\text { strain) } \\
12.5 \mu \mathrm{g} / \mathrm{mL} \\
\text { (resistant } \\
\text { strain) }\end{array}$ & Zhang et al. ${ }^{9}$ \\
\hline CATH-1 & $\begin{array}{l}\text { MRSA } \\
\text { WKZ-2 }\end{array}$ & - & $\begin{array}{l}\text { Banaschewski } \\
\text { et al. }{ }^{31}\end{array}$ & Protegrin & ATCC 25923 & $\begin{array}{l}2-16 \mu \mathrm{g} / \mathrm{mL} \\
(1-7.4 \mu \mathrm{M})\end{array}$ & $\begin{array}{l}\text { Barańska-Rybak } \\
\text { et al. }{ }^{2}\end{array}$ \\
\hline CATH-2 & MRSA & - & $\begin{array}{l}\text { Banaschewski } \\
\text { et al. }{ }^{31}\end{array}$ & Rattusin & $\begin{array}{l}\text { ATCC } 25923 \\
\text { ATCC BAA- } \\
39 \\
\text { ATCC } 43300\end{array}$ & $4-8 \mu \mathrm{g} / \mathrm{mL}$ & Patil et al. ${ }^{37}$ \\
\hline Cecropin P1 & ATCC 29213 & $\begin{array}{l}>256 \mu \mathrm{g} / \mathrm{mL} \\
(>76.7 \mu \mathrm{M})\end{array}$ & $\begin{array}{l}\text { Ebbensgaard et } \\
\text { al. }^{20}\end{array}$ & RMAD4 & $\begin{array}{l}\text { Clinical } \\
\text { isolates }\end{array}$ & $1.5-3 \mu \mathrm{M}$ & Tai et al. ${ }^{25}$ \\
\hline CRAMP & MRSA WKZ-2 & - & $\begin{array}{l}\text { Banaschewski } \\
\text { et al. } .^{31}\end{array}$ & RNase7 & $\begin{array}{l}\text { Clinical } \\
\text { isolates }\end{array}$ & - & Köten et al..$^{22}$ \\
\hline $\begin{array}{l}\text { Cryptdin-4 } \\
\text { (Crp-4) }\end{array}$ & Clinical isolates & $1.5-3 \mu \mathrm{M}$ & Tai et al..$^{25}$ & $\begin{array}{l}\text { RTD-1 (teta } \\
\text { defensin) }\end{array}$ & $\begin{array}{l}\text { Clinical } \\
\text { isolates }\end{array}$ & $1.5 \mu \mathrm{M}$ & Tai et al. ${ }^{25}$ \\
\hline eCATH1 & ATCC 29213 & $>32 \mu \mathrm{g} / \mathrm{mL}$ & $\begin{array}{l}\text { Schlusselhuber } \\
\text { et al. } .^{38}\end{array}$ & SMAP-29 & $\begin{array}{l}\text { Clinical } \\
\text { isolates }\end{array}$ & $\begin{array}{l}4-8 \mu \mathrm{g} / \mathrm{mL} \\
(1.2-2.5 \mu \mathrm{M})\end{array}$ & Pompilio et al. ${ }^{16}$ \\
\hline hLF1-11 & ATCC 33591 & $\begin{array}{l}64 \mu \mathrm{g} / \mathrm{mL} \\
(46.56 \mu \mathrm{M})\end{array}$ & Costa et al. ${ }^{8}$ & TSLP & ATCC 29213 & - & Sonesson et al. ${ }^{15}$ \\
\hline
\end{tabular}

Source: The authors.

Even though the results are not always positive, AMPs secondary effects should be considered, as they may act synergistically with traditional treatments. Several natural AMPs can modulate host defense, reducing inflammatory cytokines ${ }^{4,25,33}$ or, in other cases, increasing anti-inflammatory ones ${ }^{33}$, what may support a favorable immunity polarization. Beneficial results of these roles were already noticed when RDT-1 reduced sepsis and peritonitis mortality in mice ${ }^{25}$, or when NFL20 inhibited LPS-induced NO responses and improved survival in mice with endotoxin-induced shock ${ }^{33}$.

Beyond the $S$. aureus direct control, it is interesting to point that AMPs, such as lactoferricin B, NK-18 and LL$37^{39}$, exhibited activity against cancer cells. LL-37 stand out by also modulating inflammatory response, enhancing reepithelialization and wound healing ${ }^{19,32}$, characteristics that potentially improve host's recovery and skin protection, given that $S$. aureus infection commonly occurs across the epithelial barrier.

\section{Limitations of natural AMPs}

These peptides commonly have dual characteristics that make them both antimicrobial and cytotoxic (Table 2 ). The transition between these two activities occurs in a narrow difference of concentration, so it is difficult to establish a proper dose that could be therapeutic and the least harmful for an individual. For BMAP-27, for example, MIC is $4 \mu \mathrm{M}$, while hemolysis and macrophage toxicity occur, respectively, at $6.2 \mu \mathrm{M}$ and $20 \mu \mathrm{M}^{3}$. Furthermore, even in cases where high concentrations does not injure host's cells, it could still impair AMPs' antimicrobial potential, as was shown for LL-37, which in lower doses controlled $S$. aureus, but was ineffective in higher ones ${ }^{4}$. The obstacle is even greater when pharmacokinetic parameters, such as absorption, excretion, and half-life, are considered.

In addition, results described in some studies are not always reliable to predict and enhance AMP potential. Comparing peptides that belong to the same family, such as the cathelicidins group ${ }^{38}$ and the NK-lysins group ${ }^{35}$, it is possible to notice that some of the variants reached effectiveness against $S$. aureus, but others did not. Also, the same peptide could sometimes control just specific pathogens, being very effective for some but not for others. This occurs with TSLP, a molecule that significantly acts against to Gram negative, but not Gram positive bacteria ${ }^{15}$. Finally, assays conditions, especially salt concentration, are capable of changing AMPs results. Alpha defensins ${ }^{25}$, HD-5, and Crp- $4{ }^{37}$, although reached $S$. aureus control in a given in vitro environment, had restricted activity when tested in physiological $\mathrm{NaCl}$ concentration. 
Table 2. Natural AMPs cytotoxicity and stability, with the corresponding reference

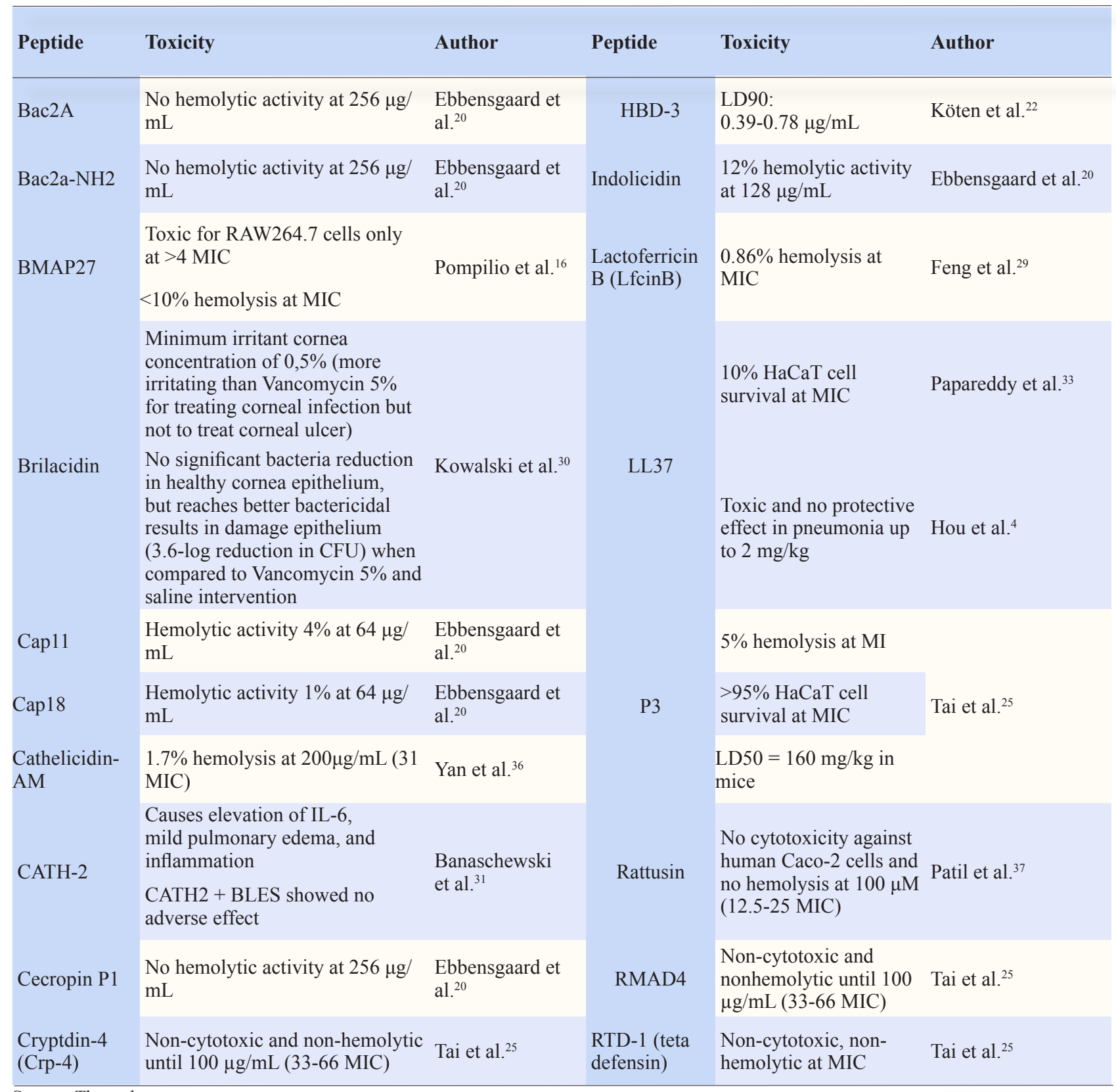

Source: The authors.

\section{Potentials of synthetic AMPs}

Synthetic peptides are a possible solution to overcome AMPs "flaws", such as cytotoxicity, low stability, and low specificity, while maintaining (or even enhancing) their antimicrobial (Table 3 ) and/or antibiofilm potential ${ }^{1}$. Hybridization of active parts of two natural peptides with different properties is a possible method to achieve this objective $^{29}$; amino acid substitution or deletion are also possibilities already being tested ${ }^{27}$.

Relations between molecular characteristics and AMP effectiveness are already being studied, so there are parameters that can be used as basis to the modifications one uses in the design of new AMPs. Hydrophobicity and cationicity are examples that are related to membrane interaction; however, increasing hydrophobicity is related to mammalian cell toxicity ${ }^{27}$ due to loss of specificity, while reducing it causes the opposite effect ${ }^{20}$. This was shown by the removal of the N-terminal hydrophobic amino acids from LL-37, which decreases its cytotoxicity without diminishing its antimicrobial effect ${ }^{7}$. Regarding positive charged amino acids of AMPs, Noore et al. ${ }^{7}$ reported, based on a study over LL-37, that the substitution of lysines for arginines decreased antistaphylococcal activity, showing that it is not only the positive charge number that is related to the AMP activity. 
Likewise, this influence of single amino acids on the overall effect of AMPs is also shown by the increase in antimicrobial activity caused by tryptophan addition; it is believed that tryptophan plays a role of anchor in membrane proteins and also helps the translocations of the AMP across the phospholipid bilayer ${ }^{40}$. Chain length and cyclization of the molecule, as well as amino acids substitution or position shifting, may also be related to reduced cytotoxicity and increased/maintained activity ${ }^{27}$, but require more investigation.

Table 3. Synthetic AMPs MICs with corresponding strain and reference

\begin{tabular}{|c|c|c|c|c|c|c|c|}
\hline Peptide & Strain & MIC & Author & Peptide & Strain & MIC & Author \\
\hline 17BIPHE2 & $\begin{array}{l}\text { Clinical } \\
\text { isolates }\end{array}$ & $1.56-3.1 \mu \mathrm{M}$ & Mishra et al. ${ }^{5}$ & LNK-16 & $\begin{array}{l}\text { ATCC } \\
25923\end{array}$ & $6 \mu \mathrm{g} / \mathrm{mL}(2.6 \mu \mathrm{M})$ & $\mathrm{Xu}$ et al. ${ }^{26}$ \\
\hline $\begin{array}{l}\text { BMAP-18 } \\
\text { analogs }\end{array}$ & $\begin{array}{l}\text { KCTC } 1621 \\
\text { (MRSA) }\end{array}$ & $4 \mu \mathrm{M}$ & Lee et al. ${ }^{3}$ & MKK34 & $\begin{array}{l}\text { ATCC } \\
29213\end{array}$ & - & $\begin{array}{l}\text { Sonesson et } \\
\text { al. }{ }^{15}\end{array}$ \\
\hline \multirow[t]{2}{*}{$\begin{array}{l}\text { BMAP-28 } \\
\text { analogs }\end{array}$} & $\begin{array}{l}\text { Clinical } \\
\text { isolates }\end{array}$ & $\begin{array}{l}3.1 \mu \mathrm{g} / \mathrm{mL} \text { (A837) } \\
2.8 \mu \mathrm{g} / \mathrm{mL} \text { (A838) } \\
2.4 \mu \mathrm{g} / \mathrm{mL} \text { (A839) } \\
3.2 \mu \mathrm{g} / \mathrm{mL} \text { (A840) }\end{array}$ & Takagi et al. ${ }^{41}$ & NK-18 & $\begin{array}{l}\text { CMCC } \\
26003\end{array}$ & \multirow[t]{2}{*}{$6.25 \mu \mathrm{g} / \mathrm{mL}$} & \multirow[t]{2}{*}{ Yan et al. ${ }^{39}$} \\
\hline & MRSA & $>5 \mu \mathrm{g} / \mathrm{mL}$ & & & & & \\
\hline $\begin{array}{l}\text { Cap11 } \\
\text { derivative } \\
\text { (Cap11-1- } \\
18 \mathrm{~m} 2)\end{array}$ & ATCC 29213 & $\begin{array}{l}16 \mu \mathrm{g} / \mathrm{mL} \\
(6.85 \mu \mathrm{M})\end{array}$ & $\begin{array}{l}\text { Ebbensgaard } \\
\text { et al. }{ }^{20}\end{array}$ & NLF20 & $\begin{array}{l}\text { ATCC } \\
29213\end{array}$ & $10-20 \mu \mathrm{M}$ & $\begin{array}{l}\text { Papareddy et } \\
\text { al. }{ }^{33}\end{array}$ \\
\hline Cys-KR12 & ATCC 25923 & $\begin{array}{l}4-8 \mu \mathrm{g} / \mathrm{mL} \\
(2.6-5.1 \mu \mathrm{M})\end{array}$ & Song et al. ${ }^{19}$ & P19(9/B) & $\begin{array}{l}\text { Clinical } \\
\text { isolates }\end{array}$ & $\begin{array}{l}\mathrm{MIC}_{50}=8 \mu \mathrm{g} / \mathrm{mL} \text { and } \\
\mathrm{MIC}_{90}=32 \mu \mathrm{g} / \mathrm{mL}\end{array}$ & $\begin{array}{l}\text { Pompilio et } \\
\text { al. }{ }^{28}\end{array}$ \\
\hline GF-17 & $\begin{array}{l}\text { Clinial } \\
\text { isolates }\end{array}$ & $1.56-3.1 \mu \mathrm{M}$ & Mishra et al. ${ }^{5}$ & P60.4Ac & $\begin{array}{l}\text { LUH } \\
14616 \\
\text { (MRSA) }\end{array}$ & - & Göblyös et al. ${ }^{12}$ \\
\hline $\begin{array}{l}\text { Indolicidin } \\
\text { analogs }\end{array}$ & ATCC 25923 & $\begin{array}{l}\text { IN1, IN2: } \\
31.25 \mu \mathrm{g} / \mathrm{mL} \\
(15.5-17.25 \mu \mathrm{M})(S \text {. } \\
\text { aureus and MRSA) } \\
\text { IN3: } 31.25 \mu \mathrm{g} / \mathrm{mL} \\
(15.7 \mu \mathrm{M}) \\
(S . \text { aureus }) \text { and } 62.5 \\
\mu \mathrm{g} / \mathrm{mL} \\
(31.4 \mu \mathrm{M})(\mathrm{MRSA}) \\
\text { IN4: } 125 \mu \mathrm{g} / \mathrm{mL} \\
(65.2 \mu \mathrm{M})(S . \\
\text { aureus }) \text { and } \\
250 \mu \mathrm{g} / \mathrm{mL} \\
(130.4 \mu \mathrm{M}) \\
(\mathrm{MRSA})\end{array}$ & Jindal et al. ${ }^{27}$ & Psoriasin & & - & Köten et al. ${ }^{22}$ \\
\hline $\begin{array}{l}\text { JH-3 (P3 } \\
\text { analog) }\end{array}$ & ATCC 29213 & $\begin{array}{l}6.25 \mu \mathrm{g} / \mathrm{mL} \\
(3.1 \mu \mathrm{M})(\text { standard } \\
\text { strain) and } 3.125 \\
\mu \mathrm{g} / \mathrm{mL}(1.6 \mu \mathrm{M}) \\
\text { (resistant strain) }\end{array}$ & Zhang et al. ${ }^{9}$ & $\begin{array}{l}\text { RN7-IN } \\
\text { (Indolicidin } \\
\text { based) }\end{array}$ & $\begin{array}{l}\text { ATCC } \\
25923 \\
\text { MRSA }\end{array}$ & $\begin{array}{l}\text { RN7-IN7: } \\
31.25 \mu \mathrm{g} / \mathrm{mL}(17.36 \\
\mu \mathrm{M}) \\
\text { RN7-IN6 = RNA7-IN8 } \\
=\text { RNA7-IN10: } 7,81 \mu \mathrm{g} / \\
\text { mL } \\
(4,55 \mu \mathrm{M})\end{array}$ & Jindal et al. ${ }^{27}$ \\
\hline LF15CA8 & ATCC 25923 & $32 \mu \mathrm{g} / \mathrm{mL}(7 \mu \mathrm{M})$ & Feng et al. ${ }^{29}$ & $\begin{array}{l}\text { Sub5-NH2 } \\
\text { (synthetic } \\
\text { variant of } \\
\text { Bac2A- } \\
\text { NH2) }\end{array}$ & $\begin{array}{l}\text { ATCC } \\
29213\end{array}$ & $\begin{array}{l}8 \mu \mathrm{g} / \mathrm{mL} \\
(4.64 \mu \mathrm{M})\end{array}$ & $\begin{array}{l}\text { Ebbensgaard } \\
\text { et al. }{ }^{20}\end{array}$ \\
\hline LFM23 & ATCC 25923 & $\begin{array}{l}32 \mu \mathrm{g} / \mathrm{mL} \\
(11 \mu \mathrm{M})\end{array}$ & Zhao et al. ${ }^{40}$ & Tet213 & $\begin{array}{l}\text { Clinical } \\
\text { isolates }\end{array}$ & - & Zhao et al. ${ }^{18}$ \\
\hline LL-16 & Newman & $\begin{array}{l}12.5 \mu \mathrm{g} / \mathrm{mL} \\
(6.11 \mu \mathrm{M})\end{array}$ & Mensa et al. ${ }^{13}$ & - & - & - & - \\
\hline
\end{tabular}

Source: The authors. 
Another important example is the stability change that synthetic peptides may achieve. 17BIPHE2, an LL37 fragment, shows increased resistance to proteolytic degradation, including by $S$. aureus protease $\mathrm{V} 8^{5}$, which degrades LL-37. On the other hand, the same authors showed that P60.4Ac, another LL-37 derived peptide, had considerable V8 susceptibility, what points that not all modifications lead to peptide improvement.

Besides their antimicrobial effects, interesting results were found, for example, for Cys-KR12 ${ }^{19}$. It acts in keratinocytes and fibroblast proliferation and keratinocytes differentiation, improving cell-cell attachment. Regarding its immunomodulatory response, Song et al. ${ }^{19}$ made a monocyte culture on a Cys-KR12-immobilized SF nanofiber membrane, and showed that this peptide interfered in monocytes TNF- $\alpha$ gene expression after LPS stimulation - and this interference may occur with other inflammatory stimuli as well. NLF20 and, to a higher extent, KYE28 (a longer peptide containing NLF20 sequence and eight amino acids more) also showed some anti-inflammatory effects ${ }^{33}$. This is of great value for the treatment of $S$. aureus skin infection, considering this is a cutaneous pathogen that is responsible for a considerable number of bacterial skin infection in humans ${ }^{2}$.

More studies that analyze how molecular changes may affect AMPs parameters, such as protease susceptibility, antimicrobial effect and cytotoxicity are needed, so that AMP design becomes as rationalized and effective as possible. Nonetheless the wide diversity of AMPs and a non-correspondence that sometimes exists between activity and structure are still limitations to face.

\section{Limitations of synthetic AMPs}

Not all modifications generate a more effective peptide, or one with reduced cytotoxicity and higher stability (Table 4). For instance, BMAP-18 analogs ${ }^{3}$ showed the same or worst results in relation to their MIC and cytotoxicity than BMAP-18 and $\theta$-defensins, as reduced disulfide bonds almost abolished bactericidal activity ${ }^{37}$, possibly due to increased susceptibility to proteolysis - in opposition to $\alpha$ - and $\beta$-defensins, which does not have their activity impaired by altering their redox status. Also, AMP activity is fragment-dependent ${ }^{15}$, as even relatively small modifications can provoke considerable changes in peptides activity. NLF20 and KYE28, for example, are very similar peptides (as discussed above, the second one contains NLF20 sequence and eight amino acids more), but NLF20 shows a stronger antimicrobial and anti-endotoxic effect, while KYE28 main effect is anti-inflammatory ${ }^{33}$.

Table 4. Synthetic AMPs cytotoxicity and stability, with the corresponding reference

\begin{tabular}{|c|c|c|c|c|c|}
\hline Peptide & Toxicity & Author & Peptide & Toxicity & Author \\
\hline 17BIPHE2 & $\begin{array}{l}\text { Non-cytotoxic, non- hemolytic } \\
\text { at MIC }\end{array}$ & Mishra et al..$^{5}$ & $\begin{array}{l}\mathrm{JH}-3 \\
\text { (P3 analog) }\end{array}$ & $\begin{array}{l}<5 \% \text { hemolysis at MIC } \\
>95 \% \mathrm{HaCaT} \text { cell survival } \\
\text { at } \mathrm{MIC} \\
\mathrm{LD} 50=180 \mathrm{mg} / \mathrm{kg} \text { in mice }\end{array}$ & Zhang et al. ${ }^{9}$ \\
\hline $\begin{array}{l}\text { BMAP-18 } \\
\text { analogs }\end{array}$ & $\begin{array}{l}\text { Non-cytotoxic for RAW } 264.7 \\
\text { cells at MIC } \\
\text { BMAP-18-W: } 10 \% \text { hemolysis at } \\
9.5 \text { MIC; } \\
\text { others at }>64 \text { MIC }\end{array}$ & Lee et al. ${ }^{3}$ & LF15CA8 & $0.54 \%$ hemolysis at MIC & Feng et al..$^{29}$ \\
\hline $\begin{array}{l}\text { Cap11 } \\
\text { derivative } \\
\text { (Cap11-1- } \\
18 \mathrm{~m} 2)\end{array}$ & $\begin{array}{l}52 \pm 6 \% \text { hemolytic activity at } \\
64 \mu \mathrm{g} / \mathrm{mL} \text { (4 MIC) }\end{array}$ & $\begin{array}{l}\text { Ebbensgaard } \\
\text { et al. }{ }^{20}\end{array}$ & LFM23 & $\begin{array}{l}0.813 \pm 0.012 \% \text { hemolysis } \\
\text { at MIC }\end{array}$ & Zhao et al..$^{40}$ \\
\hline Cys-KR12 & $\begin{array}{l}\text { No citotoxicity against } \mathrm{HaCaT} \\
\text { cells or NHDF at } \geq 100 \mu \mathrm{g} / \mathrm{mL} \\
(12.5-25 \mathrm{MIC})\end{array}$ & Song et al. ${ }^{19}$ & NLF20 & $\begin{array}{l}60-70 \% \mathrm{HaCaT} \text { cell } \\
\text { survival at MIC }\end{array}$ & Papareddy et al. ${ }^{33}$ \\
\hline GF-17 & $\begin{array}{l}\text { Non-cytotoxic, non- hemolytic } \\
\text { at MIC }\end{array}$ & Mishra et al..$^{5}$ & $\begin{array}{l}\text { RN7-IN } \\
\text { (Indolicidin based) }\end{array}$ & $<5 \%$ hemolysis at MIC & Jindal et al. ${ }^{27}$ \\
\hline $\begin{array}{l}\text { Indolicidin } \\
\text { analogs }\end{array}$ & $<5 \%$ hemolysis at MIC & Jindal et al. ${ }^{27}$ & $\begin{array}{l}\text { Sub5-NH2 } \\
\text { (synthetic variant of } \\
\text { Bac2A-NH2) }\end{array}$ & $\begin{array}{l}\text { No hemolytic activity at } 256 \\
\mu \mathrm{g} / \mathrm{mL} \text { ( } 32 \text { MIC) }\end{array}$ & Ebbensgaard et al..$^{20}$ \\
\hline
\end{tabular}

Source: The authors. 
These differences can be somewhat explained by the relatively restricted knowledge of the correlation between molecular characteristics of AMPs and their effect on bacterial membrane. One feature that probably is related to this limitation is that the majority of the studies on the interaction of cationic peptides with membranes have been developed using a liposome model ${ }^{39}$ and not bacterial membranes. Nonetheless, even with suitable study models, discrepant results in vitro and in vivo may occur; for instance, JH-3 showed the highest hemolytic effect in vitro, but the lowest value in vivo, when compared to the other AMPs analyzed".

Another important limitation of synthetic (and even natural) AMPs is their high manufacturing $\operatorname{costs}^{26}$, which would increase treatment costs, restricting its use to few special cases - or significantly hinder its use in poor countries, with very restricted resources. These high costs are related not only to the research process but also to the limited AMP expression and sometimes difficult synthesis process; thus, researches on new methods of production, with higher expression and cheaper processes, should be done to AMPs clinical use become a reality.

\section{AMP administration}

AMPs administration is a treatment's feature that can both impair or improve the peptides potentials or limitations. It approaches both the peptide inoculation site and their association with devices that carry the molecules.

Regarding peptide injection, Zhang et al. ${ }^{9}$ interestingly compared the insertion of different AMPs in mice peritoneum and subcutaneous, finding that the mortality in the first case was higher than the second one, independently of the peptide used. This raises possibilities not only to further studies' design but also to accurate others results' interpretation.

The use of devices is another alternative to slightly modify the role of AMPs. Immobilization on a surface is a strategy that commonly reduces the peptide proteolytic degradation, co-precipitation and self-aggregation, while allows AMPs gradual release, minimizing the dosedependent toxicity, a frequent side effect ${ }^{8}$. However, this also impairs antimicrobial activity ${ }^{19}$, even though this does not necessarily invalidate the AMP. The lactoferrin derivative hLF1-11, for example, despite showing higher MIC when immobilized, could decrease adherent bacteria viability in device surface, being bacteriostatic, but not bactericidal $^{8}$.

Analogous positive results were found by Banaschewski et al. ${ }^{31}$, who used a bovine lipid-extract

\section{REFERENCES}

1. Ageitos JM, Sánchez-Pérez A, Calo-Mata P, Villa TG. Antimicrobial peptides (AMPs): Ancient compounds that represent novel weapons in the fight against bacteria. surfactant (BLES) as AMP carrier. The antimicrobial activity of CRAMP, CATH-1, and LL-37 decreased, but only a slight diminution of CATH-2 activity was observed. Furthermore, the association of CATH-2 with BLES showed lower deleterious effects compared to CATH-2 alone and maintained its safety in healthy mice lung - the mild pulmonary edema and inflammation caused when instilled by itself did not occur when it was used with BLES.

This field of AMP research becomes even more relevant once it enables improvement in catheters' safe use. $S$. aureus is one of the most common causes of biomaterial-associated infections ${ }^{18}$ and AMPs insertion in these devices emerges as a possibility to control bacteria biofilm formation. In this context, a novel catheter assembly with titanium, silver, polyarginine, hyaluronic acid, and the AMP catestatin calls attention, as it shows, in vitro, lower inflammation response and higher human tolerance to implant - two majors problems associated with biomedical devices ${ }^{17}$.

\section{CONCLUSION}

S. aureus commonly belongs to humans' microbiota, being associated with worse prognostic in intensive care units due to infections that sometimes could not be completely controlled by traditional treatments. Ergo, it is desirable that novel approaches are developed, and it is in this scenario that AMPs emerge as an alternative. Nonetheless, besides some positive results in infection control, the current data and knowledge about them seem to remain scarce and even controversial.

AMPs bactericidal and bacteriostatic activities were, in some cases, restricted to a single or few research groups, which not rarely achieve discrepant results in MIC and toxicity, according to strains or experimental conditions. The wide variety of peptides and the incomprehension about how their structure impact the antimicrobial action are also considerable obstacles to advance on their therapeutic potentials. Therefore, many AMPs keep in preclinical in vitro and in vivo studies or are even neglected before having its potentials carefully analyzed.

In this scope, further researches in AMPs are needed not only to discover new molecules, but also to enable their full characterization, as well as to ensure further progress - improving cheaper manufacturing process and study designs that are closer to the animal organism, for example, in aspects of salt concentration and membrane composition. These long-term projects will possibly support the prospective clinical use of AMPs in such a relevant context as infection

Biochem Pharmacol. 2017;133:117-138. doi: 10.1016/j. bcp.2016.09.018.

2. Barańska-Rybak W, Pikula M, Dawgul M, Kamysz W, Trzonkowski P, Roszkiewicz J. Safety profile of antimicrobial 
peptides: camel, citropin, protegrin, temporin a and lipopeptide on HaCaT keratinocytes. Acta Pol Pharm. 2013;70(5):795801. Available from: http://www.ptfarm.pl/pub/File/Acta Poloniae/2013/5/795.pdf.

3. Lee EK, Kim Y-C, Nan YH, Shin SY. Cell selectivity, mechanism of action and LPS-neutralizing activity of bovine myeloid antimicrobial peptide-18 (BMAP-18) and its analogs. Peptides. 2011;32(6):1123-30. doi: 10.1016/j. peptides.2011.03.024.

4. Hou M, Zhang N, Yang J, et al. Antimicrobial Peptide LL-37 and IDR-1 Ameliorate MRSA pneumonia in vivo. Cell Physiol Biochem. 2013;32(3):614-23. doi: 10.1159/000354465.

5. Mishra B, Golla RM, Lau K, Lushnikova T, Wang G. Antistaphylococcal biofilm effects of human cathelicidin peptides. ACS Med Chem Lett. 2016;7(1):117-21. doi: 10.1021/ acsmedchemlett.5b00433.

6. Fitzgerald-Hughes D, Devocelle M, Humphreys H. Beyond conventional antibiotics for the future treatment of methicillinresistant Staphylococcus aureus infections: two novel alternatives. FEMS Immunol Med Microbiol. 2012;65(3):399412. doi: 10.1111/j.1574-695X.2012.00954.x.

7. Noore J, Noore A, Li B. Cationic Antimicrobial Peptide LL-37 Is Effective against both Extra- and Intracellular Staphylococcus aureus. Antimicrob Agents Chemother. 2013;57(3):1283-90. doi: 10.1128/AAC.01650-12.

8. Costa F, Maia S, Gomes J, Gomes P, Martins MCL. Characterization of hLF1-11 immobilization onto chitosan ultrathin films, and its effects on antimicrobial activity. Acta Biomater. 2014;10(8):3513-21. doi: 10.1016/j. actbio.2014.02.028.

9. Zhang Q, Xu Y, Wang Q, et al. Potential of novel antimicrobial peptide $\mathrm{P} 3$ from bovine erythrocytes and its analogs to disrupt bacterial membranes in vitro and display activity against drug-resistant bacteria in a mouse model. Antimicrob Agents Chemother. 2015;59(5):2835-41. doi: 10.1128/AAC.0493214.

10. Epand RM, Vogel HJ. Diversity of antimicrobial peptides and their mechanisms of action. Biochim Biophys Acta Biomembr. 1999;1462(1):11-28. doi: 10.1016/S00052736(99)00198-4.

11. Kang H-K, Kim C, Seo CH, Park Y. The therapeutic applications of antimicrobial peptides (AMPs): a patent review. J Microbiol. 2017;55(1):1-12. doi: 10.1007/s12275017-6452-1.

12. Göblyös A, Schimmel KJM, Valentijn ARPM, et al. Development of a nose cream containing the synthetic antimicrobial peptide $\mathrm{P} 60.4 \mathrm{Ac}$ for eradication of methicillinresistant Staphylococcus aureus Carriage. J Pharm Sci. 2013;102(10):3539-44. doi: 10.1002/jps.23695.

13. Mensa B, Howell GL, Scott R, DeGrado WF. Comparative mechanistic studies of brilacidin, daptomycin, and the antimicrobial peptide LL16. Antimicrob Agents Chemother. 2014;58(9):5136-45. doi: 10.1128/AAC.02955-14.

14. Cole JN, Nizet V. Bacterial evasion of host antimicrobial peptide defenses. Microbiol Spectr. 2016;4(1):VMBF-00062015. doi: 10.1128/microbiolspec.VMBF-0006-2015.

15. Sonesson A, Kasetty G, Olin AI, et al. Thymic stromal lymphopoietin exerts antimicrobial activities. Exp Dermatol. 2011;20(12):1004-10. doi: 10.1111/j.16000625.2011.01391.x.

16. Pompilio A, Scocchi M, Pomponio S, et al. Antibacterial and anti-biofilm effects of cathelicidin peptides against pathogens isolated from cystic fibrosis patients. Peptides. 2011;32(9):1807-14. doi: 10.1016/j.peptides.2011.08.002.

17. Özçelik H, Vrana NE, Gudima A, et al. Harnessing the Multifunctionality in Nature: A Bioactive Agent Release System with Self-Antimicrobial and Immunomodulatory Properties. Adv Healthc Mater. 2015;4(13):2026-36. doi: 10.1002/adhm.201500546.

18. Zhao G, Zhong H, Zhang M, Hong Y. Effects of antimicrobial peptides on Staphylococcus aureus growth and biofilm formation in vitro following isolation from implantassociated infections. Int J Clin Exp Med. 2015;8(1):15461551. Available from: https://www.ncbi.nlm.nih.gov/pmc/ articles/PMC4358626/.

19. Song DW, Kim SH, Kim HH, Lee KH, Ki CS, Park YH. Multi-biofunction of antimicrobial peptide-immobilized silk fibroin nanofiber membrane: implications for wound healing. Acta Biomater. 2016;39:146-55. doi: 10.1016/j. actbio.2016.05.008.

20. Ebbensgaard A, Mordhorst H, Overgaard MT, Nielsen CG, Aarestrup FM, Hansen EB. Comparative Evaluation of the antimicrobial activity of different antimicrobial peptides against a range of pathogenic bacteria. PLoS One. 2015;10(12):e0144611. doi: 10.1371/journal.pone.0144611.

21. Yang M, Tang M, Ma X, et al. AP-57/C10orf99 is a new type of mutifunctional antimicrobial peptide. Biochem Biophys Res Commun. 2015;457(3):347-52. doi: 10.1016/j. bbrc.2014.12.115.

22. Köten B, Becker K, Podschun R, et al. Susceptibility of Staphylococcus aureus bacteremia strains to different skin-derived antimicrobial proteins. Arch Dermatol Res. 2012;304(8):633-7. doi: 10.1007/s00403-012-1284-7.

23. Li Q, Huang J, Guo H, Guo X, Zhu Y, Dong K. Bactericidal activity against meticillin-resistant Staphylococcus aureus of a novel eukaryotic therapeutic recombinant antimicrobial peptide. Int J Antimicrob Agents. 2012;39(6):496-9. doi: 10.1016/j.ijantimicag.2012.03.003.

24. Merriman JA, Nemeth KA, Schlievert PM. Novel Antimicrobial Peptides That Inhibit Gram Positive Bacterial Exotoxin Synthesis. Otto M, ed. PLoS One. 2014;9(4):e95661. doi: 10.1371/journal.pone.0095661.

25. Tai KP, Kamdar K, Yamaki J, et al. Microbicidal effects of $\alpha$ - and $\theta$-defensins against antibiotic-resistant Staphylococcus aureus and Pseudomonas aeruginosa. Innate Immun. 2015;21(1):17-29. doi: 10.1177/1753425913514784.

26. Xu Y, Wang Q, Hang B, et al. Serial Expression and Activity Analysis of LNK-16: A Bovine Antimicrobial Peptide Analogue. Protein J. 2014;33(4):309-312. doi:10.1007/ s10930-014-9563-0.

27. Jindal HM, Le CF, Mohd Yusof MY, et al. Antimicrobial Activity of Novel Synthetic Peptides Derived from Indolicidin and Ranalexin against Streptococcus pneumoniae. PLoS One. 2015;10(6):e0128532. doi: 10.1371/journal. pone. 0128532 .

28. Pompilio A, Crocetta V, Scocchi M, et al. Potential novel therapeutic strategies in cystic fibrosis: antimicrobial and anti-biofilm activity of natural and designed $\alpha$-helical peptides against Staphylococcus aureus, Pseudomonas aeruginosa, and Stenotrophomonas maltophilia. BMC Microbiol. 2012;12:145. doi: 10.1186/1471-2180-12-145.

29. Feng X-J, Xing L-W, Liu D, et al. Design and high-level expression of a hybrid antimicrobial peptide LF15-CA8 in Escherichia coli. J Ind Microbiol Biotechnol. 2014;41(3):527- 
534. doi:10.1007/s10295-013-1382-3.

30. Kowalski RP, Romanowski EG, Yates KA, Mah FS. An Independent Evaluation of a Novel Peptide Mimetic, Brilacidin (PMX30063), for Ocular Anti-Infective. J Ocul Pharmacol Ther. 2016;32(1):23-7. doi: 10.1089/ jop.2015.0098.

31. Banaschewski BJH, Veldhuizen EJA, Keating E, et al. Antimicrobial and biophysical properties of surfactant supplemented with an antimicrobial peptide for treatment of bacterial pneumonia. Antimicrob Agents Chemother. 2015;59(6):3075-83. doi: 10.1128/AAC.04937-14.

32. Leszczynska K, Namiot D, Byfield FJ, et al. Antibacterial activity of the human host defence peptide LL-37 and selected synthetic cationic lipids against bacteria associated with oral and upper respiratory tract infections. J Antimicrob Chemother. 2013;68(3):610-18. doi: 10.1093/jac/dks434.

33. Papareddy P, Kasetty G, Kalle M, et al. NLF20: An antimicrobial peptide with therapeutic potential against invasive Pseudomonas aeruginosa infection. J Antimicrob Chemother. 2016;71(1):170-80. doi: 10.1093/jac/dkv322.

34. Jiang Y, Yi X, Li M, Wang T, Qi T, She X. Antimicrobial activities of recombinant mouse $\beta$-defensin 3 and its synergy with antibiotics. J Mater Sci Mater Med. 2012;23(7):1723-8. doi: 10.1007/s10856-012-4645-z.

35. Chen J, Huddleston J, Buckley RM, et al. Bovine NK-lysin: Copy number variation and functional diversification. Proc Natl Acad Sci. 2015;112(52):E7223-E7229. doi: 10.1073/ pnas. 1519374113.

Recebido em: 26.06.17

Aceito em: 05.12.17
36. Yan X, Zhong J, Liu H, Liu C, Zhang K, Lai R. The cathelicidin-like peptide derived from panda genome is a potential antimicrobial peptide. Gene. 2012;492(2):368-74. doi: 10.1016/j.gene.2011.11.009.

37. Patil AA, Ouellette AJ, Lu W, Zhang G. Rattusin, an intestinal alpha-defensin-related peptide in rats with a unique cysteine spacing pattern and salt-insensitive antibacterial activities. Antimicrob Agents Chemother. 2013;57(4):1823-31. doi: 10.1128/AAC.02237-12.

38. Schlusselhuber M, Guldbech K, Sevin C, et al. In vitro effectiveness of the antimicrobial peptide eCATH1 against antibiotic-resistant bacterial pathogens of horses. FEMS Microbiol Lett. 2014;350(2):216-22. doi: 10.1111/15746968.12337.

39. Yan J, Wang K, Dang W, et al. Two hits are better than one: membrane-active and DNA binding-related double-action mechanism of NK-18, a novel antimicrobial peptide derived from mammalian NK-Lysin. Antimicrob Agents Chemother. 2013;57(1):220-8. doi: 10.1128/AAC.01619-12.

40. Zhao X, Yu D, Gong H, et al. Design, synthesis and antibacterial activity of a novel hybrid antimicrobial peptide LFM23. African J Biotechnol. 2012;11(8):2107-12. doi: 10.5897/AJB11.3281

41. Takagi S, Nishimura J, Bai L, et al. Susceptibility difference between methicillin-susceptible and methicillin-resistant Staphylococcus aureus to a bovine myeloid antimicrobial peptide (BMAP-28). Anim Sci J. 2014;85(2):174-9. doi: 10.1111/asj.12098. 